\title{
Pengaruh Pemberian Edukasi terhadap Pengetahuan Keluarga Terkait Dagusibu Antibiotik di Daerah Surabaya dan Sidoarjo
}

\author{
Sarah Mahmudatun Nabila, Ifa Shintia Irianti, Salsabila, Aufa Hamidah, Fina Rahmawati, Mohamad Khoirul Faizin, \\ Muhamad Ninjar, Iva Ladzdzah Malikhah, Steffi Ordelia Valentina, Devi Nur Zafirah, Metha Beriana, Andre Alwi \\ Azhari, Abdul Rahem*
}

Departemen Farmasi Komunitas, Fakultas Farmasi, Universitas Airlangga Gedung Nanizar Zaman Joenoes Kampus C, Jl. Ir. Soekarno, Surabaya 60115, Indonesia

*E-mail: abdulrahem@ff.unair.ac.id

\begin{abstract}
ABSTRAK
Antibiotik merupakan golongan obat yang digunakan untuk mengobati pasien yang mengalami infeksi bakteri. Antibiotik harus digunakan secara rasional, tepat, dan aman. Obat antibiotik seharusnya diperoleh dengan resep dokter. Namun masyarakat banyak yang memperolehnya tanpa menggunakan resep dokter. Penelitian ini bertujuan untuk mengetahui pengaruh pemberian edukasi terkait Dapatkan, Gunakan, Simpan, dan Buang (DaGuSiBu) antibiotik di daerah Surabaya dan Sidoarjo. Pengambilan sampel dalam penelitian ini dilakukan dengan teknik non probabilitas yaitu dengan purposive sampling menggunakan kuesioner google form. Kuesioner ini berisi 19 pertanyaan dengan skor maksimal 19. Dari 178 responden, dengan 95 kelompok kontrol dan 85 kelompok perlakuan didapatkan hasil pada uji Mann-Whitney nilai $p$ value sebesar $0,000<0,05$ yang berarti terdapat perbedaan bermakna antara kelompok kontrol dan kelompok perlakuan. Hal ini membuktikan bahwa pemberian edukasi terkait DaGuSiBu antibiotik memberikan pengaruh terhadap pengetahuan responden.
\end{abstract}

Kata kunci: Antibiotik, DaGuSiBu, Keluarga

ABSTRACT

Antibiotics have been used for treating bacterial infection for years. The use of antibiotics must be rational, appropriate and safe. Antibiotics should be obtained by prescription. However, nowadays people are able to get them without using a doctor's prescription. The purpose of this study is to determine the effect of providing education related to Get, Use, Store, and Dispose of antibiotics in the Surabaya and Sidoarjo areas. Sampling in this study was conducted using nonprobability technique, namely purposive sampling using a google form questionnaire. The questionnaire contains 19 questions with a maximum score of 19 . Of the 178 respondents with 95 control groups and 85 treatment groups, MannWhitney test shows a $p$ value of $0.000(<0.05)$, indicating a significant difference between the control and treatment groups. This proves that the provision of education related to Get, Use, Store, and Dispose of antibiotics has a positive relation on respondent's knowledge.

Keywords: Antibiotics, DaGuSiBu, Family 


\section{PENDAHULUAN}

Di Indonesia penyakit infeksi menjadi masalah utama dalam bidang kesehatan, sebab mempunyai angka prevalensi yang tinggi. Salah satu terapi penyakit infeksi adalah dengan menggunakan antibiotik (Rusmini et al., 2019). Tingginya prevalensi ini menyebabkan tingginya penggunaan antibiotik (Dirga et al., 2021). Penggunaan antibiotik memerlukan pertimbangan klinis yang tepat untuk memenuhi rasionalitas sehingga menjamin keamanan, ketepatan dan efektivitas yang maksimal. Penggunaan antibiotik secara rasional mutlak menjadi keharusan. Penggunaan antibiotik secara rasional diartikan sebagai pemberian antibiotik yang tepat indikasi, tepat penderita, tepat obat, tepat dosis, dan waspada terhadap efek samping antibiotik (Utami, 2012).

Penggunaan antibiotik sebagai swamedikasi (pengobatan sendiri) merupakan salah satu bentuk penggunaan antibiotika yang tidak tepat atau tidak rasional (Kemenkes RI, 2013). Hasil penelitian mengenai penggunaan antibiotik di apotek menunjukkan tingkat penggunaan antibiotik tanpa resep sebesar $75,90 \%$ terhadap total penjualan antibiotik (Yuana, 2016). Berdasarkan penelitian lain yang dilakukan terhadap masyarakat yang pernah membeli antibiotik tanpa resep, diketahui bahwa tingkat pengetahuan responden terhadap antibiotik yang masuk kategori "kurang" adalah sebesar 56,44\%. Masih banyak responden yang menganggap penggunaan antibiotik dapat diulang tanpa resep dokter untuk gejala penyakit yang sama $(89,89 \%)$; semua antibiotik memiliki cara dan efek yang sama (48,09\%); antibiotik tidak harus diminum sampai habis $(47,73 \%)$; antibiotik dalam bentuk sirup untuk anak masih dapat digunakan setelah lebih dari 2 minggu (37,63\%); dan antibiotik dapat disimpan sebagai persediaan untuk digunakan sewaktu-waktu $(53,31 \%)$ (Ihsan et al., 2016). Berdasarkan data dari Riskesdas (2013), di Indonesia sebanyak 35,2\% rumah tangga menyimpan obat untuk swamedikasi, dan dari persentase tersebut sebanyak $27,8 \%$ merupakan antibiotik dan $86,1 \%$ menyimpan antibiotik hasil pembelian tanpa resep.

Penggunaan antibiotik yang tidak tepat akan menimbulkan masalah resistensi yang berdampak pada morbiditas dan mortalitas penyakit infeksi (Ihsan et al., 2016). Resistensi antibiotik adalah kemampuan bakteri untuk bertahan hidup dari efek serangan antibiotik semakin lama semakin meningkat. Hal ini dapat terjadi apabila bakteri mengubah dirinya sehingga efektivitas obat, bahan kimia, atau bahan lain yang dirancang untuk membunuh bakteri pun berkurang. Hal ini menyebabkan bakteri kebal terhadap antibiotik dan berkembang biak yang akan mengakibatkan efek terapi sulit dicapai (Rusmini et al., 2019). Berdasarkan laporan dari WHO dalam Antimicrobial Resistance: Global report on
Surveillance menunjukkan bahwa Asia Tenggara memiliki angka tertinggi dalam kasus resistensi antibiotik di dunia, khususnya infeksi yang disebabkan oleh Staphylococcus aureus yang resisten terhadap Methicillin, sehingga mengakibatkan menurunnya fungsi antibiotik tersebut (WHO, 2004). Hasil penelitian resistensi antimikroba di Indonesia pada tahun 2000-2004 di RSUD Dr. Soetomo Surabaya dan RSUD dr. Kariadi Semarang, membuktikan maraknya persebaran kuman multiresisten seperti MRSA (Methicillin Resistant Staphylococcus aureus) dan bakteri penghasil ESBL (Extended Spectrum Beta Lactamase) (Kemenkes RI, 2011). Hasil pengabdian masyarakat Antimicrobial Resistant in Indonesia (AMRIN-Study) terbukti dari 2.494 individu di masyarakat, $43 \%$ Escherichia coli resisten terhadap berbagai jenis antibiotik antara lain: ampisilin (34\%), kotrimoksazol (29\%) dan kloramfenikol (25\%) (Kemenkes, 2011).

Informasi obat dan pengobatan merupakan bagian yang tidak terpisahkan dari proses terapi rasional (BPOM RI, 2014). Oleh karena itu, upaya yang dapat dilakukan apoteker untuk meningkatkan rasionalitas pengobatan dan mencegah resistensi adalah dengan meningkatkan kesadaran keluarga dalam mendapatkan, menggunakan, menyimpan, dan membuang antibiotik melalui pelayanan Komunikasi, Informasi, dan Edukasi (KIE). Apoteker diharapkan dapat berperan aktif dalam memberikan informasi, konseling, dan edukasi kepada pasien secara individual maupun kepada masyarakat secara umum (Kemenkes RI, 2011). Tujuan dari penelitian ini adalah untuk mengetahui pengaruh pemberian informasi terhadap pengetahuan keluarga terkait pengadaan, penggunaan, penyimpanan, dan pembuangan terhadap antibiotik.

\section{METODE PENELITIAN}

\section{Desain penelitian}

Penelitian ini termasuk jenis penelitian quasi experimental yaitu eksperimen yang memiliki perlakuan, pengukuran dampak, unit eksperimen, namun tidak menggunakan penugasan acak untuk menciptakan perbandingan dalam rangka menyimpulkan perubahan yang disebabkan perlakuan. Rancangan yang digunakan adalah nonequivalent control group posttest-only design.

Pengambilan sampel pada penelitian ini dilakukan dengan teknik purposive sampling dengan kriteria inklusi yaitu responden berusia $\geq 18$ tahun dan dalam keadaan sehat, bukan mahasiswa atau tenaga dalam bidang kesehatan, tinggal bersama keluarga dan sudah pernah mengkonsumsi antibiotik oral, berdomisili di Surabaya atau Sidoarjo. Dari sampel yang telah didapat, dikelompokkan sesuai kelompok kontrol dan kelompok perlakuan. 
Kelompok kontrol adalah sekelompok responden yang tidak menerima video edukasi dan kelompok perlakuan adalah responden yang menerima video edukasi. Adapun video yang diberikan berdurasi kurang lebih 7 menit, dimana berisikan penjelasan mengenai antibiotik dan $\mathrm{DaGuSiBu}$ antibiotik serta peneliti memberikan ilustrasi terkait $\mathrm{DaGuSiBu}$ antibiotik dengan harapan dapat memberikan pemahaman yang lebih jelas kepada responden. Responden yang masuk ke dalam kelompok kontrol maupun kelompok perlakuan ditentukan secara acak (peneliti tidak secara sengaja mengelompokkan responden tertentu ke dalam kelompok tertentu).

\section{Instrumen survei}

Instrumen yang digunakan dalam penelitian ini yaitu google form yang berisi lembar informasi, lembar persetujuan menjadi responden, dan lembar kuesioner tertutup. Lembar informasi berisi tentang prosedur penelitian, sehingga responden mengetahui apa yang akan dilakukan ketika ikut serta dalam penelitian. Lembar persetujuan menjadi responden diisi setelah membaca lembar informasi yang digunakan sebagai bukti kesediaan responden untuk mengikuti prosedur penelitian. Lembar kuesioner tertutup berisi pertanyaan-pertanyaan yang dapat digunakan untuk mengukur tingkat pengetahuan responden.

Pengambilan data dilakukan dengan cara melakukan personal chat melalui WhatsApp dengan responden yang memenuhi kriteria inklusi. Penulis berbagi tugas mencari responden untuk kelompok kontrol dan responden untuk kelompok perlakuan. Waktu pengambilan data dilakukan serempak pada 10 Oktober 2020.

Uji validitas kuesioner dilakukan pada 12 responden sesuai dengan kriteria inklusi. Uji validitas yang dilakukan mencakup uji validitas isi dan konstruk. Uji validitas isi dilakukan dengan mencari pustaka yang sesuai dari pernyataan dalam kuesioner dan dikonfirmasi oleh ahli yang dalam hal ini yaitu dosen pembimbing. Selanjutnya dilakukan uji validitas konstruk dan dapat dilihat pada Tabel 1 bahwa diperoleh 18 pernyataan yang valid dilihat dari $r$ hitung lebih dari $r$ tabel. Selanjutnya uji reliabilitas kuesioner dilakukan pada responden yang sama dengan uji validitas. Hasil uji reliabilitas dari 18 butir pernyataan yang telah valid menunjukkan alpha cronbach sebesar 0,980 yang berarti bahwa alpha cronbach lebih dari 0,6 sehingga dapat disimpulkan kuesioner reliabel dan dapat digunakan sebagai instrumen penelitian.

Terdapat 19 pertanyaan untuk melihat pengetahuan responden terkait $\mathrm{DaGuSiBu}$ antibiotik dengan nilai skor untuk jawaban benar $=1$ dan jawaban salah $=0$. Data yang diperoleh selanjutnya diproses menggunakan Software Statistical Package for the Social Sciences (SPSS) versi 25.0. Data hasil skor responden dianalisis menggunakan uji MannWhitney.

\section{HASIL DAN PEMBAHASAN}

Pada penelitian ini, target awal perolehan responden berjumlah 120 responden dengan 60 responden kelompok kontrol dan 60 responden kelompok perlakuan. Pada kenyataannya diperoleh 183 responden. Namun, hanya 178 responden yang memenuhi kriteria inklusi, dimana terdapat 4 responden yang memiliki usia di bawah 18 tahun sehingga tidak masuk ke dalam kriteria dan 1 responden yang tidak bersedia mengisi kuesioner. Kelompok kontrol sebanyak 93 responden dan kelompok perlakuan sebanyak 85 responden.

Table 1. Data Demografi Responden Kelompok Kontrol dan Perlakuan

\begin{tabular}{|c|c|c|c|}
\hline \multirow{2}{*}{ Demografi } & \multirow{2}{*}{ Keterangan } & $\mathrm{N}(\%)$ & $\mathrm{N}(\%)$ \\
\hline & & Kontrol & Perlakuan \\
\hline \multirow[t]{6}{*}{ Usia (tahun) } & $18-20$ & $31(33,33)$ & $16(18,82)$ \\
\hline & $21-23$ & $40(43,01)$ & $48(56,47)$ \\
\hline & $24-26$ & $2(2,15)$ & $1(1,18)$ \\
\hline & $27-29$ & $1(1,08)$ & $2(2,35)$ \\
\hline & $\geq 30$ & $19(20,43)$ & $18(21,18)$ \\
\hline & Total & $93(100,00)$ & $85(100,00)$ \\
\hline \multirow[t]{3}{*}{ Jenis Kelamin } & Laki-laki & $33(35,48)$ & $28(32,94)$ \\
\hline & Perempuan & $60(64,52)$ & $57(67,06)$ \\
\hline & Total & $93(100,00)$ & $85(100,00)$ \\
\hline \multirow[t]{3}{*}{ Domisili } & Surabaya & $73(78,49)$ & $68(80,00)$ \\
\hline & Sidoarjo & $20(21,51)$ & $17(20,00)$ \\
\hline & Total & $93(100,00)$ & $85(100,00)$ \\
\hline
\end{tabular}


Berdasarkan hasil penelitian seperti pada Tabel 1 menunjukkan bahwa responden terbanyak pada rentang usia 21-23 tahun baik untuk kelompok kontrol maupun perlakuan, yaitu sejumlah 40 orang $(43,01 \%)$ untuk kelompok kontrol dan 48 orang $(56,47 \%)$ untuk kelompok perlakuan. Hal ini dikarenakan pada pengambilan data banyak disebarkan kepada rekanrekan yang sebaya dengan peneliti. Responden perempuan lebih banyak dari laki-laki baik untuk kelompok kontrol maupun perlakuan, yaitu sejumlah 60 orang $(64,52 \%)$ untuk kelompok kontrol dan 57 orang $(67,06 \%)$ untuk kelompok perlakuan. Domisili mayoritas adalah Surabaya, dengan responden untuk kelompok kontrol sejumlah 73 orang $(78,49 \%)$, dan untuk kelompok perlakuan sejumlah 68 orang $(80,00 \%)$. Keuntungan dari responden yang mayoritas berusia 21-23 tahun yang merupakan usia produktif ini, diharapkan dapat lebih mudah memahami informasi dan aktif menyebarkan informasi yang diperoleh kepada kerabat dan rekannya. Sehingga diharapkan dapat mengurangi penyalahgunaan antibiotik dan mencegah resistensi antibiotik sedini mungkin.

Pada kelompok perlakuan sebanyak $82,4 \%$ responden dan kelompok kontrol sebanyak $60,1 \%$ menjawab benar mengenai 3 pertanyaan terkait pengetahuan terhadap antibiotik seputar tujuan dan maksud penggunaan antibiotik. Untuk pengetahuan terkait cara mendapatkan antibiotik, persentase jawaban benar dari 4 pertanyaan yang diberikan kepada responden kelompok perlakuan adalah 87,4\% dan $69,5 \%$ untuk kelompok kontrol. Pengetahuan terkait penggunaan antibiotik diukur melalui 6 butir pertanyaan yang diberikan kepada responden, dengan persentase jawaban yang benar pada kelompok perlakuan 93,9\% dan kelompok kontrol 85,7\%. Dari 85 responden kelompok perlakuan, 96,3\% memiliki pengetahuan yang baik terhadap penyimpanan antibiotik dengan menjawab 3 butir pertanyaan pada kuesioner, serta 90,3\% kelompok kontrol memiliki pengetahuan yang baik. Namun untuk pengetahuan terkait cara pembuangan antibiotik, persentase responden kelompok perlakuan yang menjawab benar adalah $70,6 \%$ dari 3 pertanyaan yang diberikan, dari hasil analisis data ditemukan bahwa 60 dari 85 responden kelompok perlakuan tidak mengetahui bahwa antibiotik yang belum habis (dikarenakan alergi, dsb.) dapat dikembalikan ke apotek. Sedangkan pada kelompok kontrol didapat persentase $51,4 \%$, dimana 79 responden kelompok kontrol belum mengetahui bahwa antibiotik yang belum habis dikarenakan alergi atau penyebab lainnya dapat dikembalikan ke apotek.

\section{Pengaruh Pemberian Edukasi DaGuSiBu terhadap Pengetahuan Keluarga}

Dari hasil pengolahan data hasil skor kuesioner rata-rata kelompok perlakuan, yaitu 16,6471 lebih besar dibandingkan hasil skor kuesioner rata-rata kelompok kontrol, yaitu 14,3978. Sebelum dilakukan analisis pengaruh pemberian edukasi Dapatkan, Gunakan, Simpan, dan Buang (DaGuSiBu) antibiotik, terlebih dahulu dilakukan uji normalitas pada data yang telah didapatkan menggunakan uji normalitas Kolmogorov-Smirnov. Suatu data berdistribusi normal jika nilai sig atau $p$ value $>0,05$. Hasil uji menunjukkan nilai $p$ value sebesar $0,000<0,05$. Berdasarkan nilai tersebut, dapat disimpulkan bahwa data tidak berdistribusi normal. Selanjutnya dilakukan uji Mann-Whitney untuk mengetahui ada atau tidaknya perbedaan bermakna antara kelompok kontrol dan kelompok perlakuan. Hasil uji MannWhitney menunjukkan nilai U sebesar 2080,500 dan nilai $\mathrm{W}$ sebesar 6451,500. Apabila dikonversikan ke nilai $\mathrm{Z}$ maka besarnya $-5,507$. Nilai sig atau $p$ value sebesar $0,000<0,05$. Apabila nilai $p$ value $<$ batas kritis 0,05 , maka terdapat perbedaan bermakna antara dua kelompok atau yang berarti $\mathrm{H} 1$ diterima.

Tabel 2. Hasil Uji Statistik, Uji Normalitas, dan Uji MannWhitney

\begin{tabular}{|c|c|c|c|c|}
\hline \multirow{2}{*}{ 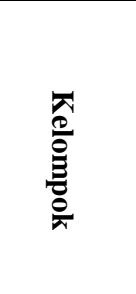 } & \multicolumn{2}{|c|}{ Uji Statistik } & \multirow{2}{*}{$\begin{array}{c}\text { Uji } \\
\text { Normali- } \\
\text { tas } \\
\text { Kolmogo- } \\
\text { rov } \\
\text { Smirnov } \\
P<0.05\end{array}$} & \multirow{2}{*}{$\begin{array}{c}\begin{array}{c}\text { Uji } \\
\text { Mann- } \\
\text { Whitney }\end{array} \\
P<0.05\end{array}$} \\
\hline & Mean & SD & & \\
\hline Kontrol & $\begin{array}{c}14.39 \\
78\end{array}$ & $\begin{array}{c}3.190 \\
13\end{array}$ & 0.000 & \multirow{2}{*}{0.000} \\
\hline Perlakuan & $\begin{array}{c}16.64 \\
71 \\
\end{array}$ & $\begin{array}{c}2.223 \\
82 \\
\end{array}$ & 0.000 & \\
\hline
\end{tabular}

Berdasarkan hasil analisis yang telah dijabarkan di atas, dapat diketahui bahwa terdapat perbedaan yang bermakna antara kelompok perlakuan, yaitu kelompok yang diberikan edukasi terkait Dapatkan, Gunakan, Simpan, dan Buang (DaGuSiBu) antibiotik sebelum mengisi kuesioner, dengan kelompok kontrol yang mengisi kuesioner tanpa mendapatkan edukasi terlebih dahulu. Hasil ini menunjukkan bahwa adanya pengaruh pemberian edukasi terhadap pengetahuan.

Beberapa penelitian sebelumnya menunjukkan hal yang sama, yaitu pada penelitian yang dilakukan oleh Trepka et al. (2001) menyatakan bahwa pemberian edukasi dapat meningkatkan pengetahuan dan kesadaran orang tua terkait penggunaan antibiotik yang benar dan potensi resistensi antibiotik pada anak. Dalam penelitian lain yang dilakukan oleh Rawson et al. (2018) menyimpulkan bahwa pemberian informasi terkait infeksi, terapi antibiotik serta efek sampingnya pada pasien dapat meningkatkan pengetahuan. Dalam penelitian Baroroh et al. (2018) menyimpulkan bahwa pemberian edukasi mampu meningkatkan 
pengetahuan tentang antibiotik. Penelitian yang dilakukan oleh Elsa (2019) juga menunjukkan bahwa pemberian edukasi tentang penggunaan antibiotik memberikan pengaruh terhadap pengetahuan, sikap, dan tindakan masyarakat.

Pada penelitian sebelumnya juga menunjukkan terdapat hubungan yang bermakna antara pengetahuan dan perilaku penggunaan antibiotik. Penelitian oleh Pratiwi (2018) tentang hubungan pengetahuan dan sikap terhadap rasionalitas perilaku penggunaan antibiotik pada masyarakat sekampung Kabupaten Lampung Timur menunjukkan hubungan yang bermakna antara pengetahuan dan perilaku penggunaan antibiotik. Penelitian lain juga dilakukan oleh Hani (2019) menunjukkan bahwa pengetahuan masyarakat dan perilaku penggunaan antibiotik memiliki hubungan yang bermakna. Lalu, berdasarkan penelitian yang dilakukan Nuraini et al. (2018) menunjukkan bahwa pengetahuan dan keyakinan pasien berpengaruh terhadap kepatuhan dalam menggunakan antibiotik secara signifikan.

Berdasarkan hasil penelitian yang telah dipaparkan, dapat diambil kesimpulan bahwa pemberian edukasi dapat meningkatkan pengetahuan, dan dengan meningkatnya pengetahuan akan mengubah perilaku. Pengetahuan merupakan domain yang sangat penting dalam membentuk tindakan atau perilaku seseorang (Fitriani, 2011). Menurut penelitian yang telah dilakukan oleh Zulkarni (2019), terdapat hubungan antara pengetahuan keluarga tentang apoteker dan antibiotik dengan pengetahuan keluarga dalam memperoleh dan menggunakan obat antibiotik. Hal ini menunjukkan bahwa apoteker memiliki peranan penting dalam usaha meningkatkan pengetahuan keluarga mengenai antibiotik guna mencegah terjadinya resistensi antibiotik. Salah satu metode yang bisa digunakan adalah dengan memberikan edukasi.

\section{KESIMPULAN}

Berdasarkan hasil penelitian mengenai Pengaruh Pemberian Edukasi Terhadap Pengetahuan Keluarga di daerah Surabaya dan Sidoarjo yang melibatkan 178 responden dapat disimpulkan bahwa pemberian edukasi terkait Dapatkan, Gunakan, Simpan, dan Buang (DaGuSiBu) antibiotik berpengaruh terhadap pengetahuan keluarga di daerah Surabaya dan Sidoarjo diukur dengan menggunakan kuesioner.

Apoteker perlu memberikan informasi tambahan terkait Dapatkan, Gunakan, Simpan, dan Buang (DaGuSiBu) antibiotik untuk mengurangi penyalahgunaan antibiotik dan mencegah resistensi antibiotik sedini mungkin.

\section{Keterbatasan Penelitian}

Dalam studi yang menggunakan nonequivalent control group post-test only design, intervensi diterapkan untuk kelompok eksperimen, yang kemudian dibandingkan dengan kelompok kontrol non-ekuivalent dan pengukuran hasil diambil dari kedua kelompok. Namun, karena tidak ada pretest, hampir tidak ada informasi tentang seberapa mirip pengaruh variabel yang diminati untuk setiap kelompok, terutama variabel hasil. Selain itu, pengendalian terhadap variabel luar tidak sekuat true eksperimental. Tujuan analisis dalam non-ekuivalen control group post-test-only design adalah untuk mengetahui pengaruh suatu intervensi dibandingkan dengan kondisi kontrol dengan membandingkan skor post-test dalam dua kelompok non-ekuivalen (Krishnan, 2018).

Pengambilan sampel dilakukan dengan teknik purposive sampling yang memiliki keterbatasan tidak adanya jaminan bahwa jumlah sampel yang digunakan representatif dalam segi jumlah, teknik sampling tidak sebaik random sampling karena adanya kemungkinan bias pada hasil penelitian, dan tidak dapat digunakan sebagai generalisasi untuk mengambil kesimpulan statistik.

\section{UCAPAN TERIMA KASIH}

Dalam proses penyelesaian manuskrip, peneliti banyak mendapatkan bantuan, masukan dan dukungan dari berbagai pihak. Oleh karena itu, tak lupa penulis menyampaikan terimakasih kepada:

1. Dosen pembimbing praktikum Farmasi Masyarakat.

2. Masyarakat di wilayah Surabaya dan Sidoarjo yang telah berpartisipasi untuk menjadi responden.

\section{DAFTAR PUSTAKA}

BPOM RI. (2014) Informatorium Obat Nasional Indonesia (IONI). Badan Pengawas Obat dan Makanan Republik Indonesia. Jakarta. http://pionas.pom.go.id/ioni/pedoman-umum.

Badan Penelitian dan Pengembangan Kesehatan Kementerian Kesehatan RI. (2013) 'Penyajian Pokok-Pokok Hasil Riset Kesehatan Dasar', Kementerian Kesehatan Republik Indonesia.

Baroroh, Hanif Nasiatul, Esti Dyah Utami, Laksmi Maharani, dan Ika Mustikaningtias. (2018) 'Peningkatan Pengetahuan Masyarakat Melalui Edukasi Tentang Penggunaan Antibiotik Bijak dan Rasional', Ad-Dawaa Jour.Pharm.Sci. 1(1), pp. 8-15. 
Dirga, Khairunnisa, S., Akhmad, A., Setyawan, I. dan Pratama, A. (2021) 'Evaluasi Penggunaan Antibiotik pada Pasien Rawat Inap di Bangsal Penyakit Dalam RSUD. Dr. H. Abdul Moeloek Provinsi Lampung', Jurnal Kefarmasian Indonesia, 11(1), pp.65-75

Elsa, Christi M. (2019) 'Pengaruh Edukasi Terhadap Pengetahuan, Sikap, dan Tindakan Masyarakat di Desa Siantartonga-Tonga I Kecamatan SiantarNarumonda Kabupaten Toba Samosir Tentang Penggunaan Antibiotika', Politeknik Kesehatan Kemenkes Medan, Medan.

Fitriani, S. (2011) Promosi Kesehatan (Edisi 1). Yogyakarta: Graha Ilmu.

Hani, Laili. (2019) 'Hubungan Pengetahuan Masyarakat terhadap Perilaku Penggunaan Antibiotik pada Konsumen Apotek di Kecamatan Glagah Kabupaten Lamongan. Skripsi', Universitas Islam Negeri Maulana Malik Ibrahim Malang.

Ihsan, S., Kartina dan Akib, N. (2016) 'Studi Penggunaan Antibiotik Non Resep di Apotek Komunitas Kota Kendari', Media Farmasi. 13(2), pp.272-284

Rusmini, Hetti, Adnan, Dalfian, Setiawati, Octa, dan Febianti. (2019) 'Hubungan Antara Dukungan Keluarga Dengan Kepatuhan Minum Obat Pada Pasien yang Mendapatkan Terapi Antibiotik di Poli Penyakit Dalam Rumah Sakit Pertamina Bintang Amin Bandar Lampung', Jurnal Dunia Kesmas, 8(2), pp. 86-94. doi: https://www.statistikian.com/2017/06/penjelasa n-teknik-purposive-sampling.html

Nuraini, Rika, Fauna, Setiasih. (2018) 'Hubungan Pengetahuan dan keyakinan dengan Kepatuhan Menggunakan Antibiotik Pasien Dewasa',
Jurnal Program Studi Magister Ilmu Farmasi: Fakultas Farmasi Universitas Surabaya, 8(4), Pp. 165-174.

Pratiwi, Arilinia. (2018) 'Hubungan Pengetahuan dan Sikap Terhadap Rasionalitas Perilaku Penggunaan Antibiotik pada Masyarakat Sekampung Kabupaten Lampung Timur', Skripsi, Universitas Sumatera Utara.

Krishnan, Preetha. (2018) 'A review of the nonequivalent control group posttest-only design', Nurse researcher, 26(2)

Rawson, et al. (2018) 'Development of a patientcentred intervention to improve knowledge and understanding of antibiotic therapy in secondary care', Antimicrob Resist Infect Control, 7(43)

Trepka, Mary J, Edward A. Belongia, Po-Huang Chyou, Jeffrey P. Davis and Benjamin Schwartz. (2001) 'The Effect of a Community Intervention Trial on Parental Knowledge and Awareness of Antibiotic Resistance and Appropriate Antibiotic Use in Children', Pediatrics, 107(1)

Utami, Eka Rahayu. (2012) 'Antibiotik, Resistensi, Dan Rasionalitas Terapi', Saintis, 1(4), pp. 191-98.

Yuana, Derryl. (2016) 'Gambaran Penggunaan Antibiotik dengan Resep dan Tanpa Resep Dokter di Beberapa Apotek di Area Jember Kota', Skripsi, Universitas Jember.

Zulkarni R, Ria Afrianti, Putri Maqfira. (2019) 'Gambaran Pengetahuan Keluarga dalam Mendapatkan dan Menggunakan Obat Antibiotik di Kecamatan Lima Kaum Kabupaten Tanah Datar', Jurnal Sains Farmasi \& Klinis, 6(1), pp. 63-68. 